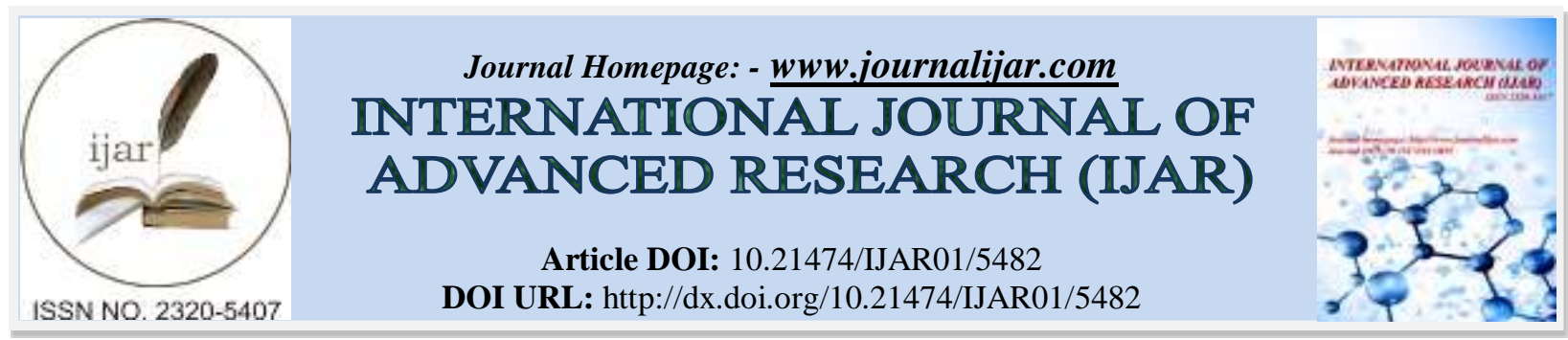

RESEARCH ARTICLE

\title{
KNOWLEDGE OF ANTIBIOTIC USE AND RESISTANCE: A QUESTIONNAIRE STUDY AMONG 100 IRAQI UNDERGRADUATE PHARMACY STUDENTS.
}

Israa N Al Mitwali.

Al Rasheed University College of Pharmacy in Baghdad Iraq.

\section{Manuscript Info}

Manuscript History

Received: 20 July 2017

Final Accepted: 22 August 2017

Published: September 2017

Key words:-

Knowledge; antibiotic use; antibiotic resistance; undergraduate pharmacy students.

\begin{abstract}
Introduction: Antibiotic resistance is one of the greatest threats to universal health. The decreasing activity of antibiotics in treating common infections has been hastened in recent years. Overuse and misuse of antibiotics in humans and animals is accelerating this process.Steps can be taken at all levels of society to limit the spread of resistance. It is critical that people and even future medical field members should understand the problem. Objectives: are to assess students' knowledge about use of antibiotics in human and agriculture, and antibiotic resistance. Methodology: A cross-sectional, questionnaire-based survey was undertaken among fourth year undergraduate pharmacy students. A total of 100 questionnaires were collected. Microsoft Office Excel 2007 was utilized to generate percentages. SPSS version 23 was used to analyze data, Chi square test $\mathrm{P}<0.001$ was used to assess the association between variables. Results: $61 \%$ of students reported having antibiotic within the last month, 33\% had their antibiotic with prescription, and $87 \%$ took it from the pharmacy. $83 \%$ of answers said that they would stop antibiotic after finishing the course. $25 \%$ mentioned cold and flu required antibiotic therapy. Student heard mostly about terms like antibiotic resistance $100 \%$, pharmacist and doctor were significantly $\mathrm{p}<0.001$ the major source of knowing these terms. While only $39 \%$ identified the term superbugs. $82 \%$ of students correctly answered the true and false questions of 'antibiotic resistance is an issue that could affect me or my family'. 52\% of students agreed with 'farmers should give fewer antibiotics to food-producing animals. Conclusions: This survey reveals good knowledge about antibiotic use and antibiotic resistance related issues. Also it displays that Iraqi medical curriculum improves students' knowledge. The study also shows an excessive use of antibiotics, this highlights the need for stricter governmental rules about antibiotic sale in community pharmacies.
\end{abstract}

Copy Right, IJAR, 2017,. All rights reserved.

\section{Introduction:-}

In the past few billion years, life has override all the difficulties to survive, Microbes are considered to be the longest living in our planet due to their great flexibility, they can be adapt to live in extreme environments. Microbes are able to live constantly in ices and boiling waters, great $\mathrm{pHs}$ and excessive high pressures. [1] 
The main cause of death and diseases in pre-antibiotic era was infections, rheumatic fever, syphilis, cellulitis and bacterial pneumonia, [2] the history of managing infections started in the First World War, as a result of poor sanitation, many soldiers lost their limbs and lives due to the infected wounds. Consequently, these problems developed rapid changes in the treatments and understanding of infections. [3]

Before the extensive use of antibiotics in 1920s and 1930s, many infections were successfully treated with phage therapy for short.[4] Syphilis was treated with inorganic mercury salts, however this treatment wasn't very efficient and it had severe side effects.[5] Antimicrobials were first introduced in 1937 with the discovery of the first effective antimicrobials called Sulfonamides, its therapeutic uses were afflicted later due to the development of specific resistance mechanisms.[6] Modern era of medicine transformed when Sir Alexander Fleming discovered the penicillin in 1928. Since then antibiotics saved millions of lives. [7] Antibiotics were first prescribed in the 1940s to treat serious infections. Many soldiers of World War II with bacterial infections were effectively treated and controlled with Penicillin. [7] Subsequently, tuberculosis was treated via Streptomycin in 1944. [6]

Indeed, the absolute reductions in mortality provided by antibiotics are practically unparalleled in the annals of medical pharmacotherapy. The absolute diminishing in death mediated by antibiotic therapy includes $25 \%$ for community-acquired pneumonia, $30 \%$ for nosocomial pneumonia, $75 \%$ for endocarditis, and $60 \%$ for meningeal or cerebral infections. [8]

Decades afterwards, bacterial infection became a threat again, a problem of antibiotic resistance raised because of the extreme use and misuse of antibiotics, not to mention the reduced economic stimulus and challenging regulatory requirements prevented the drug development by the pharmaceutical industry. [7]

Originally, drug resistant strains were discovered in hospitals, because supreme antibiotics were used in hospitals. For example, in 1930s Sulfonamide-resistant Streptococcus pyogenes appeared in military hospitals. Same as Mycobacterium tuberculosis resisting strains to streptomycin arose very soon after the antibiotic was introduced to the community. [9] Furthermore, antibiotic-resistant gonorrhea spread to USA world wide after it's first development in Vietnam in 1967, then to Philippines. As well as NDM eznymes are prevelent worldwide after being reported for the first time in 2008. [10]

Drug resistance emerges when antibiotic and the resistance genes in microorganisms selected by the antibiotic come together in a host, this can lead to a clinical problem. Selected resistance genes and their hosts spread under continued antimicrobial selection to extend the problem to other hosts and other geographic locations. Drug resistance is mobile; the genes for resistance traits can be transferred among bacteria of different groups by means of mobile genetic elements such as plasmids. These genes are generally directed against a single family or type of antibiotic, although multiple genes, each bearing a single drug resistance trait, can accumulate in the same organism. [9] Figure 1 explains how antibiotic resistance occurs. [11]

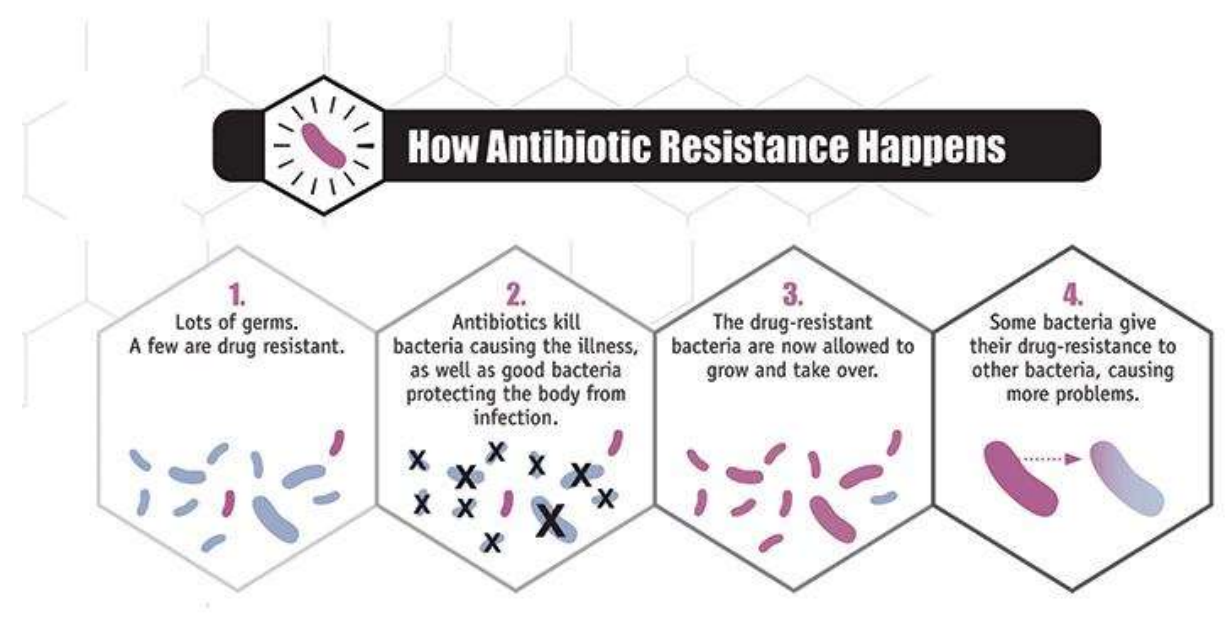

Fig. 1:-how antibiotic resistance happens 
The principles of antibiotic resistance are complex and include human behavior at many degrees of society; the outcomes affect everybody in the world. [10] The reasons may include excessive use, incorrect prescribing, over agricultural use, availability of little new antibiotics, and regulatory limits. [7]

The decreasing activity of antibiotics in treating common infections has been hastened in recent years, and with the incoming of untreatable strains of carbapenem-resistantEnterobacteriaceae, we are at the dawn of a post-antibiotic era. [10] A post-antibiotic era means, things as common as strep throat or a child's scratched knee could once again kill. [12]

Complicated interventions, like hip replacements, organ transplants, cancer chemotherapy, and care of preterm infants, would become too dangerous to undertake because antibiotic resistance will occur to all new antibiotics. [12] Antibiotic resistance is one of the greatest threats to universal health. It can affect anyone, of any age, country. Despite the fact that antibiotic resistance happens naturally, overuse and misuse of antibiotics in humans and animals is hastening this process. [13] Steps can be taken at all levels of society to limit the spread of resistance, including the public and health care professional. [8] Beside we must redefine our responsibility as members of our communities. [8] It is critical that people and even future medical field members should understand the problem, and the way in which they can change their behavior. Young pharmacists and physicians should have more teaching during their undergraduate education regarding appropriate prescribing and antibiotic resistance. [14] Better understanding of what the students know and believe about the issues of antibiotics use and resistance can assist in planning an effective educational intervention for them.

\section{Aim of the study:-}

Assess students' knowledge about use of antibiotics, use of antibiotics in agriculture and their knowledge and attitude concerning antibiotic resistance.

\section{Method:-}

This study is a cross-sectional, questionnaire-based survey which was undertaken in Al-Rasheed University College of Pharmacy in Baghdad- Iraq after taking ethical approval from head of department of Al-Rasheed University College of pharmacy in Baghdad Iraq, and distributed among fourth year undergraduate students after they have received teaching on antibiotics in their pharmacology classes. All the participants were briefly told about the objectives of the study before requesting them to fill the questionnaire. The study started in December 2016 for two months. A total of 130 questionnaires were distributed to the students, and 100 questionnaires were filled and collected. The questionnaire (refer to an appendix1[13] consisted of two sections, demographic data (gender and age) and 13 antibiotics related questions, where as the first four questions were used to assess the students' usage of antibiotics, two of them were of Yes/No type and two needed to select one answer from multiple choice questions. Then series of four questions which were intended to study students' knowledge about antibiotics, two of these were of the True/False type and one was of the Yes/No type. The students' knowledge about antibiotic resistance was assessed by using a set of four questions, two of these were a five-point Likert scale based questions which ranged from 'agree strongly' to 'Disagree strongly'. The last question was about students' knowledge about using of antibiotics in agriculture, and it was Yes/No type question. Microsoft Office Excel 2007 was utilized to generate percentages and other results. SPSS version 23 was used to analyze the data, Chi square $\mathrm{X}^{2}$ test was used to assess the association between dependent and independent variables, $\mathrm{P}<0.001$ was considered as significant association.

\section{Result:-}

The response rate was $76.9 \%$ among the 130 students who were asked to participate in the survey. The average age was 22 years old. They were 64 females and 36 males.

\section{Use of antibiotics:-}

This section covers when students last took antibiotics, how and where they obtained them. Results explained in percentages as shown in table 1 . By using $\mathrm{x}^{2}$ test there was no significant statistical difference between answers of males and females regarding the use of antibiotics.

\begin{tabular}{|l|l|l|l|}
\hline Item & Question & Use Of Antibiotics & Correct \% \\
\hline \multirow{2}{*}{1} & When did you last take an antibiotic? & More than a year ago & $\mathbf{9 \%}$ \\
\cline { 3 - 4 } & & Within the last year & $\mathbf{4 \%}$ \\
\hline
\end{tabular}




\begin{tabular}{|c|c|c|c|}
\hline & & Within the last 6 months & $19 \%$ \\
\hline & & Within the last month & $61 \%$ \\
\hline & & Never & $2 \%$ \\
\hline & & Can't remember & $5 \%$ \\
\hline 2 & Did a doctor prescribe it for you? & Yes & $33 \%$ \\
\hline & & No & $65 \%$ \\
\hline & & I can't remember & $2 \%$ \\
\hline 3 & $\begin{array}{l}\text { Did you get an advice from a } \\
\text { doctor/pharmacist on how to take }\end{array}$ & $\begin{array}{l}\text { Yes, I received an advice on how to } \\
\text { take them (e.g. with food, for } 7 \text { days) }\end{array}$ & $65 \%$ \\
\hline & them? & No & $32 \%$ \\
\hline & & I can't remember & 3\% \\
\hline 4 & Where did you get the antibiotics & A pharmacy & $87 \%$ \\
\hline & from? & A friend or a family member & $9 \%$ \\
\hline & & $\begin{array}{l}\text { I had them saved up from a previous } \\
\text { time }\end{array}$ & $2 \%$ \\
\hline & & I can't remember & $2 \%$ \\
\hline
\end{tabular}

Tab 1:-Percentages of correct answer to questions about antibiotic use.

Knowledge about antibiotics:-

Findings of this part of the study covered the levels of knowledge of the students about the appropriate use of antibiotics. Results explained in percentages as shown in table 2. By using $\mathrm{x}^{2}$ test there was no significant statistical difference between answers of males and females regarding the knowledge of antibiotics.

\begin{tabular}{|c|c|c|c|}
\hline Item & Question & Knowledge about antibiotics & Correct \% \\
\hline \multirow[t]{3}{*}{1} & \multirow[t]{3}{*}{$\begin{array}{l}\text { When do you think you should stop taking } \\
\text { antibiotics once you've begun treatment? }\end{array}$} & $\begin{array}{l}\text { After finishing the correct course } \\
\text { of the antibiotic }\end{array}$ & $83 \%$ \\
\hline & & When you feel better & $14 \%$ \\
\hline & & I don't know & $3 \%$ \\
\hline \multirow[t]{2}{*}{2} & \multirow{2}{*}{$\begin{array}{l}\text { Do you think this statement is true or false? "It's } \\
\text { okay to use antibiotics that were given to a } \\
\text { friend or family member, as long as they were } \\
\text { used to treat the same illness" }\end{array}$} & FALSE & $92 \%$ \\
\hline & & TRUE & $8 \%$ \\
\hline \multirow[t]{3}{*}{3} & \multirow{3}{*}{$\begin{array}{l}\text { Do you think this statement is true or false? "It's } \\
\text { okay to buy the same antibiotics, or request } \\
\text { them from a doctor, if you're sick and they have } \\
\text { helped you get better when you had the same } \\
\text { symptoms in a previous time." }\end{array}$} & FALSE & $54 \%$ \\
\hline & & TRUE & $32 \%$ \\
\hline & & I don't know & $14 \%$ \\
\hline \multirow[t]{12}{*}{4} & \multirow{12}{*}{$\begin{array}{l}\text { Do you think these conditions can be treated } \\
\text { with antibiotics? }\end{array}$} & HIV*/AIDS** & $84 \%$ \\
\hline & & Gonorrhea & $57 \%$ \\
\hline & & $\begin{array}{l}\text { Bladder infection or urinary tract } \\
\text { infection (UTI) }\end{array}$ & $100 \%$ \\
\hline & & Diarrhea & $85 \%$ \\
\hline & & Cold and flu & $75 \%$ \\
\hline & & Fever & $71 \%$ \\
\hline & & Malaria & $69 \%$ \\
\hline & & Measles & $68 \%$ \\
\hline & & Skin or wound infection & $99 \%$ \\
\hline & & Sore throat & $62 \%$ \\
\hline & & Body aches & $87 \%$ \\
\hline & & Headaches & $98 \%$ \\
\hline
\end{tabular}

Tab 2:-Percentages of correct answers to questions of knowledge about antibiotics.

HIV*: human imuno deficiency virus, AIDS**: acquired imuno deficiency syndrome. 


\section{Knowledge of antibiotic resistance:-}

This part presents responses to questions exploring levels of awareness of the issue of antibiotic resistance and levels of understanding of the issue and how to address it.

\subsection{Awareness of terms connected to antibiotic resistance and sources of information.}

Students were asked whether they had heard of terms usually used in issue related to antibiotic resistance, results shown in table 3.

\begin{tabular}{|c|c|c|c|c|c|c|c|c|}
\hline Item & Terms & Doctor & Pharmacist & $\begin{array}{l}\text { Family } \\
\text { member/ } \\
\text { Friend }\end{array}$ & $\begin{array}{l}\text { Social } \\
\text { Media }\end{array}$ & $\begin{array}{l}\text { Newspaper, } \\
\text { TV, radio }\end{array}$ & $\begin{array}{l}\text { Specific } \\
\text { campaign }\end{array}$ & $\begin{array}{l}\text { Never } \\
\text { heard } \\
\text { about }\end{array}$ \\
\hline 1 & $\begin{array}{l}\text { Antibiotic } \\
\text { resistance }\end{array}$ & $20 \%$ & $69 \%$ & $2 \%$ & $7 \%$ & $2 \%$ & $0 \%$ & $0 \%$ \\
\hline 2 & $\begin{array}{l}\text { Antimicrobial } \\
\text { resistance }\end{array}$ & $34 \%$ & $49 \%$ & $5 \%$ & $3 \%$ & $1 \%$ & $0 \%$ & $8 \%$ \\
\hline 3 & Superbugs & $17 \%$ & $11 \%$ & $2 \%$ & $5 \%$ & $4 \%$ & $0 \%$ & $61 \%$ \\
\hline 4 & AMR & $11 \%$ & $22 \%$ & $0 \%$ & $4 \%$ & 0\% & $0 \%$ & $63 \%$ \\
\hline 5 & Drug resistance & $16 \%$ & $70 \%$ & $6 \%$ & $2 \%$ & $1 \%$ & $\mathbf{0}$ & $5 \%$ \\
\hline 6 & $\begin{array}{l}\text { Antibiotic-resistant } \\
\text { bacteria }\end{array}$ & $5 \%$ & $74 \%$ & $15 \%$ & $4 \%$ & $0 \%$ & $0 \%$ & $2 \%$ \\
\hline
\end{tabular}

Tab 3:- Percentages of students' awareness about terms used in issue related to antibiotic resistance and the source of information. AMR: antimicrobial resistance.

In general, the expression with the highest level of awareness is antibiotic resistance, $100 \%$ of students have heard the term before. Followed by drug resistance $95 \%$ and antibiotic-resistant bacteria $98 \%$. By using $\mathrm{x}^{2}$ test, there was significant association between students' answers to the terms antibiotic resistance and antimicrobial resistance $\mathrm{p}<0.001$, as 41 students identify the two terms from the pharmacist source and 14 students identify the two terms from doctor source. In the same way there was significant association between students' answers to the terms antibiotic resistance and antibiotic resistance bacteria $\mathrm{p}<0.001$, as 53 students identify the two terms from the pharmacist source and only 3 students identify the two terms from doctor source. AMR and superbugs terms represented the highest percentages of never heard before among the students, also there was significant association between students' answers to the terms AMR and superbugs $\mathrm{p}<0.001$, as 43 students never heard about the two terms.

3.2 Levels of understanding of the issue of antibiotic resistance

In general, some statements are appropriately identified by greater number of students while others are not as displayed in Table 4

\begin{tabular}{|l|l|l|}
\hline Item & Question & Correct $\%$ \\
\hline 1 & $\begin{array}{l}\text { Antibiotic resistance occurs when your body becomes resistant to antibiotics and they } \\
\text { no longer work as well }\end{array}$ & $\mathbf{3 1 \%}$ \\
\hline $\mathbf{2}$ & $\begin{array}{l}\text { Many infections are becoming increasingly resistant to treatment by antibiotics } \\
\text { If bacteria are resistant to antibiotics, it can be very difficult or impossible to treat the } \\
\text { infections they cause }\end{array}$ & $\mathbf{6 9 \%}$ \\
\hline $\mathbf{3}$ & Antibiotic resistance is an issue that could affect me or my family & $\mathbf{8 2 \%}$ \\
\hline $\mathbf{5}$ & Antibiotic resistance is an issue in other countries but not here & $\mathbf{7 8 \%}$ \\
\hline $\mathbf{6}$ & Antibiotic resistance is only a problem for people who take antibiotics regularly & $\mathbf{6 0 \%}$ \\
\hline 7 & Bacteria which are resistant to antibiotics can be spread from person to person & $\mathbf{5 8 \%}$ \\
\hline $\mathbf{8}$ & $\begin{array}{l}\text { Antibiotic-resistant infections could make medical procedures like surgery, organ } \\
\text { transplants and cancer treatment much more dangerous }\end{array}$ & $\mathbf{5 6 \%}$ \\
\hline
\end{tabular}

Tab 4:-Percentages of correct answers to statements intended to conclude knowledge of antibiotic resistance

3.3 Levels of awareness and understanding around ways to address antibiotic resistance.

The five-point response options of the Likert scale were reduced into three, such as agree/neither agree nor disagree/disagree to simplify the results and for statistical analysis purposes. 
The majority of students agreed that all of these actions would help to reduce the problem, People should consume antibiotics only when they are prescribed by a doctor $100 \%$ and Parents should make sure all of their children's vaccinations are up-to-date $97 \%$. But, there is some incorrect interpretation with few statements as shown in Table 5

\begin{tabular}{|c|c|c|c|c|}
\hline Item & Statements & Agree & $\begin{array}{l}\text { Neither } \\
\text { agree nor } \\
\text { disagree }\end{array}$ & Disagree \\
\hline 1 & $\begin{array}{l}\text { People should use antibiotics only when they are prescribed by } \\
\text { a doctor }\end{array}$ & $100 \%$ & $\mathbf{0 \%}$ & $\mathbf{0 \%}$ \\
\hline 2 & $\begin{array}{l}\text { Farmers should give fewer antibiotics to food-producing } \\
\text { animals }\end{array}$ & $52 \%$ & $\mathbf{2 8 \%}$ & $20 \%$ \\
\hline 3 & $\begin{array}{l}\text { People should not keep antibiotics and use them later for other } \\
\text { illnesses }\end{array}$ & $\mathbf{8 0 \%}$ & $4 \%$ & $16 \%$ \\
\hline 4 & $\begin{array}{l}\text { Parents should make sure all of their children's vaccinations } \\
\text { are up-to-date }\end{array}$ & $97 \%$ & $2 \%$ & $1 \%$ \\
\hline 5 & People should wash their hands regularly & $94 \%$ & $1 \%$ & $5 \%$ \\
\hline 6 & Doctors should only prescribe antibiotics when they are needed & $94 \%$ & $6 \%$ & $\mathbf{0 \%}$ \\
\hline 7 & Governments should reward the development of new antibiotics & $94 \%$ & $4 \%$ & $2 \%$ \\
\hline 8 & Pharmaceutical companies should develop new antibiotics & $90 \%$ & $6 \%$ & $4 \%$ \\
\hline
\end{tabular}

Tab 5:- Percentages of students who answered to "Do you think the following actions would help address the problem of antibiotic resistance?"

3.4 People's opinions on the degree of the problem of antibiotic resistance and whether it will influence them personally

Responses to this question explored a blend of views:

$88 \%$ of students agreed that I am worried about the impact that antibiotic resistance will have on my health, and my family, $80 \%$ of students believed that everyone should take responsibility for using antibiotics responsibly, but $78 \%$ of students also thought that medical experts will solve the problem of antibiotic resistance. $70 \%$ of students think that they are not at risk of an antibiotic-resistant infection as long as they take their antibiotics correctly, but $79 \%$ of respondents also thought that it is one of the biggest problems in the world.

It is also important to note that $58 \%$ agreed that "There are not many people like me can do to stop antibiotic resistance" with only $23 \%$ disagreeing with this statement.

Use of antibiotics in agriculture:-

As well, this survey illustrates the students knowledge about the use of antibiotics in agriculture (including in foodproducing animals) if they using widely. $37 \%$ said I don't know, $32 \%$ said yes and $31 \%$ said no.

By using $\mathrm{x}^{2}$ test there was significant association $\mathrm{p}<0.001$ between answers of students to "farmers should give fewer antibiotics in food-producing animals" in the previous portion of the results and answers to "do you think antibiotics are widely used in agriculture (including in food-producing animals) in your country?" 20 students agreed with both questions.

\section{Discussion:-}

The strength of this study is that it addresses a major universal issue of antibiotic use and resistance. Also it is the first study that has ever taken place in examining the use of antibiotics, levels of knowledge about appropriate use of antibiotics and understanding of the problem of antibiotic resistance among Iraqi undergraduate fourth year pharmacy students in Baghdad, in the form of questionnaire.

The study found that students were of high quality in terms of knowledge on antibiotic use, but poor in behaviors. The results of this study of antibiotic use presented how frequently antibiotics are taken, with a considerable proportion of students $61 \%$ reported having antibiotics within the last month and $2 \%$ have never taken antibiotics. The results of the survey questions on how people obtained antibiotics, show just $33 \%$ have taken antibiotic from doctor's prescription, which points out high ratio of self- medication and the antibiotics are not more likely to be taken correctly. 
On the other hand notably is the fact that 85 students mentioned that they acquired the antibiotics from pharmacy and 65 student have gotten advice from doctor or pharmacist on how to use them, these explore that the antibiotic have been taken in the proper manner.

Despite the fact that the results of the study section to estimate students' knowledge of the appropriate use of antibiotics shows proportionately great levels of understanding, but there is evidence of incorrect interpretation about buying the same antibiotics, or requesting these from a doctor if they're sick and they helped them to recover when they had the same illness as before." $32 \%$ think this is true and $14 \%$ didn't know if it is true or false, while in fact, it is false, because doctors should prescribe antibiotics, after testing to identify if antibiotics are necessary or not and if they are, which specific antibiotics are needed.

A high level of knowledge was noticed in students to when to stop taking antibiotic? $83 \%$ think that they should stop it after finishing the course. In another study among medical students in Southern India, 74.2\% would finish the full course of antibiotic. [15] But other study conducted in China showed nearly half of the university students believed that they could stop treatment as soon as their symptoms had disappeared. [16] In fact bacterial resistance comes from stopping antibiotic therapy immediately after the symptoms decrease as this exposes the infecting bacteria to sub therapeutic levels of the drug. [17] On the other hand recently published analysis announced that it's time for physicians to bring down the message of "failing to complete a prescribed antibiotic course leads to antibiotic resistance" as there is no evidence supporting this message. [18] Students were questioned to indicate which of a list of medical problems could be managed with antibiotics, the list included conditions that can and cannot be treated with antibiotics. Actually, understanding which conditions can be managed with antibiotics is also significant as the use of antibiotics for conditions which are not treatable with antibiotics is another contributor to misuse, and to the development of resistance. The results show some misunderstanding, $16 \%$ think that HIV can be treated by antibiotics, one-quarter of respondents believe that cold and flu can be treated by an antibiotic, and 29\% thought that antibiotic can treat fever. In similar study among second year medical students in Southern Indian after taking pharmacology class, $38 \%$ of them reported that antibiotics should be taken upon developing cold and 60\% agreed that antibiotic can help in fever. [15] These results are proportionately weak compared to results of other study which shows only 5\% of answers were incorrect about the use of antibiotic in cold and flu. [19] While in fact antibiotics usually kill bacteria, but not viruses and can help in fever which caused by bacterial infection only. [13] That means the surveyed students have good information about using antibiotic in cold and fever.

$38 \%$ said that sore throat can be treated by an antibiotic. Also in similar study in China $18.9 \%$ of medical students believed that antibiotics can cure a sore throat. [20] Similarly in another study among medical students in Southern Indian $19.6 \%$ agreed with using antibiotics in sore throat. [15] In fact antibiotics active only against bacterial infections such as Streptococcal pharyngitis, after carrying out a throat culture. [21]

Regarding the threat of antibiotic resistance, it is fundamental that students were aware of the significance of the antibiotic resistance, its outcome and how to deal with it.

The level of awareness and understanding was explained by asking students if they had heard of a series of commonly used expressions towards the issue. The results reveal that students heard about important expressions like antibiotic resistance $89 \%$, antimicrobial resistance $83 \%$, drug resistance $86 \%$, antibiotic-resistant bacteria $79 \%$, the source significantly most mentioned $\mathrm{p}<0.001$ was doctor and pharmacist, mainly pharmacist, proposing that health care professionals play significant role in creating awareness regarding the issue, and incorrect prescribing of antibiotics. It is, of course, important that the students are aware of the issue and understand it. But, the results also presented significantly p $<0.00161 \%$ of students did not heard about Superbugs, and 63\% of AMR.

The study attempted to found levels of understanding by requesting students to mark whether a set of statements about antibiotic use were true or false. Enormous ratio of students properly identifies some statements, but $69 \%$ of students thought that antibiotic resistance happens as their body turns into resistant to antibiotics.

Students were also questioned whether they thought some of possible activities would help to limit the threat of antibiotic resistance. The greater number $94 \%$ of students agreed that persons must usually wash their hands.

Then students were asked if they agree or not with statements on the threat of antibiotic resistance, the results demonstrate high level of knowledge but some misunderstanding as $40 \%$ of students thought that they are not in 
danger of an antibiotic-resistant infection, since they take their antibiotics properly. But in fact antibiotic-resistant bacteria can scattered and then can be extended throughout the world. [22]

$82 \%$ of students were concerned about the influence of antibiotic resistance on their health and their family's health. Also in China $81.9 \%$ agreed that antibiotic resistance affects them and their family's health. [23]

$79 \%$ of students showed that antibiotic resistance is one of the greatest hazards that face the world. While in another study in the northeast United States results show approximately all students $92 \%$ believed in "Hospitals face serious problems with antibiotic resistant organisms",. [24]

Also, this study explains the students' knowledge about using of antibiotics in agriculture (including in foodproducing animals) if they are being used widely, the results showed little knowledge in this mode, $37 \%$ of students don't know about that, and $31 \%$ of students said No, these result were significantly associated $\mathrm{p}<0.001$ with the answer to farmers should give fewer antibiotics to food-producing animals, where as 20 students agree to both questions and 17 students did not know about the two questions. In another published study among medical students in Southern Indian $54.6 \%$ of them agreed with overuse of antibiotic in live stock is important. [15]

The use of antibiotics as an animal food supplement is common, especially in North America. [25] But there is limited data about these practices in the Middle East. Two studies showed that antibiotic supplementation of animal feed might be familiar, to the lower extant in Saudi Arabia. A study in 22 farms showed that animal liver and muscle tissues were inspected for antibiotic residues. Norfloxacin was identified in $35 \%$ of muscle tissues and $56.7 \%$ liver tissues. [26] Other study of farms in Saudi Arabia, tetracycline residues were recognized in domestic fowl products from 60 and $69.7 \%$ of broiler and egg-laying operations, respectively. [27]

\section{Conclusions and Recommendation:-}

This survey of 100 pharmacy students reveals good knowledge about antibiotic and antibiotic resistance related issues, the results were in line with other published studies. Also the study outcome displays that Iraqi medical curriculum significantly improves students' knowledge. Beside pharmacist and doctors were the major sources of knowledge of important terms related to antibiotic resistance. On the other side the study shows an excessive use of antibiotics among students, reflecting a deficiency of antibiotics usage instructions in their curriculum also this highlights the need for stricter governmental rules about antibiotic use and sale in community pharmacies.

There should be supervision on antibiotic use in the agriculture sector because of their participation in antibiotic resistance, not use antibiotics in animals to prevent diseases, vaccinate animals and use alternatives to antibiotics when available, according toWorld Health Organization recommendation. [13]

Establishment of a special course on the rational prescription of antibiotics that emphasizes more on the behavior of the students towards antibiotics use is recommended.

Pharmacy students should make a plan to enhance their awareness and understanding of antibiotic use and antibiotic resistance through effective communication, education, and training because they will have a responsibilityfor health problems.

A future study is recommended to detect the knowledge of antibiotic use and resistance of general population of patients attending community pharmacy, in order to measure the awareness of them and to give attention to how dangerous this problem is, and how it can affect the society. Further studies are requested to determine the level of awareness of local farmers about feeding antibiotic to food producing animals and the consequence of this.

\section{Acknowledgements:-}

The author would like to thank the collaboration of colleagues, pharmacist ReemWael and biotechnologist Marwa Al Mitwali in this work, also the head of department of Al Rasheed University College, Pharmacy Department Dr Abdulwahab Al Shekhly and the fourth year Al Rasheed pharmacy students 2016-2017. This survey study dedicated to dear husband Murtadha Al Ani for his faithful support. 
Appendices

Appendix 1

Demographics

What's your gender?

1. Male

2. Female

what's your age?

Main questionnaire

Use of antibiotics

1) When did you last take an antibiotic

1. In the last month

2. In the last 6 months

3. In the last year

4. More than a year ago

5. Never

6. Can't remember

If 'Never', go straight to Question 5.

2) Did a doctor prescribe it for you?

1. Yes

2. No

3. Can't remember

3) On that occasion, did you get advice from a doctor, nurse or pharmacist on how to take them?

1. Yes, I received advice on how to take them (e.g. with food, for 7 days)

2. No

3. Can’t remember

4) On that occasion, where did you get the antibiotics?

1. Medical store or pharmacy

2. The internet

3. Friend or family member

4. I had them saved up from a previous time

5. Somewhere/someone else

6. Can't remember

Knowledge About Antibiotics

5) When do you think you should stop taking antibiotics once you've begun treatment?

1. When you feel better

2. When you've taken all of the antibiotics as directed

3. Don't know

6) Do you think this statement is 'true' or 'false'?

"It's okay to use antibiotics that were given to a friend or family member, as long as they were used to treat the same illness"

1. True

2. False

3. Don't know

4.

7) Do you think this statement is 'true' or 'false'?

"It's okay to buy the same antibiotics, or request these from a doctor, if you're sick and they helped you get better when you had the same symptoms before"

1. True

2. False 


\section{Don't know}

8) Do you think these conditions can be treated with antibiotics?

\begin{tabular}{|l|l|l|l|}
\hline Item & Conditions & Yes & NO \\
\hline $1-$ & HIV/AIDS & & \\
\hline $2-$ & Gonorrhea & & \\
\hline $3-$ & Bladder infection or urinary tract infection (UTI) & & \\
\hline $4-$ & Diarrhea & & \\
\hline $5-$ & Cold and flu & & \\
\hline $6-$ & Fever & & \\
\hline $7-$ & Malaria & & \\
\hline $8-$ & Measles & & \\
\hline $9-$ & Skin or wound infection & & \\
\hline $10-$ & Sore throat & & \\
\hline $11-$ & Body aches & & \\
\hline $12-$ & Headaches & \\
\hline
\end{tabular}

\section{Knowledge About Antibiotic Resistance}

9) Where have you heard about the following terms?

\begin{tabular}{|c|c|c|c|c|c|c|c|c|}
\hline item & Terms & $\begin{array}{l}\text { Doctor } \\
\text { or } \\
\text { nurse }\end{array}$ & Pharmacist & $\begin{array}{l}\text { Family } \\
\text { member } \\
\text { or } \\
\text { friend }\end{array}$ & $\begin{array}{l}\text { social } \\
\text { media }\end{array}$ & $\begin{array}{l}\text { Media } \\
\text { (newspaper, } \\
\mathrm{TV}, \text { radio) }\end{array}$ & $\begin{array}{l}\text { Specific } \\
\text { campaign }\end{array}$ & $\begin{array}{l}\text { Never } \\
\text { heard } \\
\text { about }\end{array}$ \\
\hline $1-$ & $\begin{array}{l}\text { Antibiotic } \\
\text { resistance }\end{array}$ & & & & & & & \\
\hline $2-$ & $\begin{array}{l}\text { Antimicrobial } \\
\text { resistance }\end{array}$ & & & & & & & \\
\hline $3-$ & Superbugs & & & & & & & \\
\hline 4- & AMR & & & & & & & \\
\hline $5-$ & Drug resistance & & & & & & & \\
\hline 6- & $\begin{array}{l}\text { Antibiotic-resistant } \\
\text { bacteria }\end{array}$ & & & & & & & \\
\hline
\end{tabular}

10) Please indicate whether you think the following statements are true or false

\begin{tabular}{|l|l|l|l|}
\hline 1 & $\begin{array}{l}\text { Antibiotic resistance occurs when your body becomes resistant to } \\
\text { antibiotics and they no longer work as well }\end{array}$ & False \\
\hline 2 & $\begin{array}{l}\text { Many infections are becoming increasingly resistant to treatment by } \\
\text { antibiotics }\end{array}$ & $\begin{array}{l}\text { True } \\
\text { to bacteria are resistant to antibiotics, it can be very difficult or impossible }\end{array}$ & \\
\hline 3 & Antibiotic resistance is an issue that could affect me or my family & & \\
\hline 5 & Antibiotic resistance is an issue in other countries but not here & & \\
\hline 6 & $\begin{array}{l}\text { Antibiotic resistance is only a problem for people who take antibiotics } \\
\text { regularly }\end{array}$ & & \\
\hline 7 & $\begin{array}{l}\text { Bacteria which are resistant to antibiotics can be spread from person to } \\
\text { person }\end{array}$ & $\begin{array}{l} \\
\text { Antibiotic-resistant infections could make medical procedures like surgery, } \\
\text { organ transplants and cancer treatment much more dangerous }\end{array}$ & \\
\hline 8
\end{tabular}

11) On the scale shown, how much do you agree the following actions would help address the problem of antibiotic resistance?

\begin{tabular}{|l|l|l|l|l|l|l|}
\hline problem of antibiotic resistance? & $\begin{array}{l}\text { Agree } \\
\text { Strongly }\end{array}$ & $\begin{array}{l}\text { Agree } \\
\text { Slightly }\end{array}$ & $\begin{array}{l}\text { Neither } \\
\text { agree nor }\end{array}$ & $\begin{array}{l}\text { Disagree } \\
\text { Slightly }\end{array}$ & $\begin{array}{l}\text { Disagree } \\
\text { Strongly }\end{array}$ \\
\hline
\end{tabular}




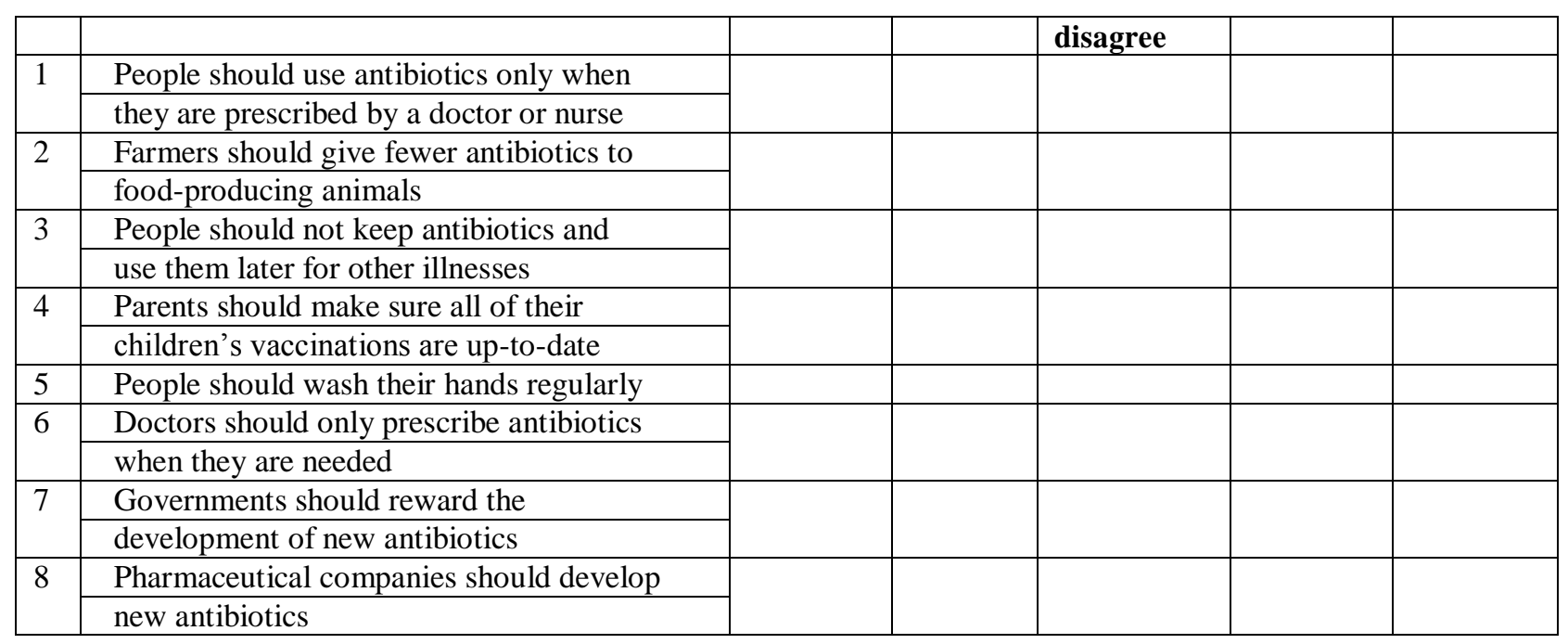

12) On the scale shown, how much do you agree with following statements?

\begin{tabular}{|c|c|c|c|c|c|c|}
\hline & & $\begin{array}{l}\text { Agree } \\
\text { Strongly }\end{array}$ & $\begin{array}{l}\text { Agree } \\
\text { Slightly }\end{array}$ & $\begin{array}{l}\text { Neither } \\
\text { Agree } \\
\text { Nor } \\
\text { Disagree }\end{array}$ & $\begin{array}{l}\text { Disagree } \\
\text { Slightly }\end{array}$ & $\begin{array}{l}\text { Disagree } \\
\text { Strongly }\end{array}$ \\
\hline 1 & $\begin{array}{l}\text { Antibiotic resistance is one of the biggest } \\
\text { problems the world faces }\end{array}$ & & & & & \\
\hline 2 & $\begin{array}{l}\text { Medical experts will solve the problem of } \\
\text { antibiotic resistance before it becomes } \\
\text { too serious }\end{array}$ & & & & & \\
\hline 3 & $\begin{array}{l}\text { Everyone needs to take responsibility for } \\
\text { using antibiotics responsibly }\end{array}$ & & & & & \\
\hline 4 & $\begin{array}{l}\text { There is not much people like me can do } \\
\text { to stop antibiotic resistance }\end{array}$ & & & & & \\
\hline 5 & $\begin{array}{l}\text { I am worried about the impact that } \\
\text { antibiotic resistance will have on my } \\
\text { health, and that of my family }\end{array}$ & & & & & \\
\hline 6 & $\begin{array}{l}\text { I am not at risk of getting an antibiotic- } \\
\text { resistant infection, as long as I take my } \\
\text { antibiotics correctly. }\end{array}$ & & & & & \\
\hline
\end{tabular}

Use of antibiotics in

Agriculture

13) Do you think antibiotics are widely used in agriculture (including in food-producing animals) in your country?
1. Yes
2. No
3. Don't know

\section{References:-}

1. Rodríguez-Rojas A, Rodríguez-Beltrán J, Couce A, Blázquez J. Antibiotics and antibiotic resistance: a bitter fight against evolution.Int J Med Microbiol.2013; 303(6-7):293-7

2. Wright, Gerard D. Q\&A: Antibiotic resistance: where does it come from and what can we do about it? $B M C$ biology 2010; 8.1: 123 .

3. Runcie H (2015) Infection in a Pre-Antibiotic Era.J Infect Dis Preve Med 2015; 3:125. doi:10.4172/23298731.1000125

4. Sulakvelidze A. Mini review: bacteriophage therapy. AAC 2001; 45(3):649-659. 
5. Aminov, Rustam I. A brief history of the antibiotic era: lessons learned and challenges for the future. Front. Microbial.2010; 134.

6. Davies, Julian, and Dorothy Davies. Origins and evolution of antibiotic resistance. MMBR 2010; 74.3: 417-433.

7. Ventola, C. Lee. The antibiotic resistance crisis: part 1: causes and threats. Pharmacy and Therapeutics 2015 40.4: 277.

8. Spellberg B. The future of antibiotics. Critical Care. 2014; 18(3):228.

9. Levy, Stuart B., and Bonnie Marshall. Antibacterial resistance worldwide: causes, challenges and responses. Nat med 2004; 10: S122-S129.

10. Laxminarayan, Ramanan, et al. Antibiotic resistance - the need for global solutions. Lancet Infect Dis.2013; 13.12: 1057-1098.

11. Liu, Bo, and Mihai Pop. ARDB — antibiotic resistance genes database. Nucleic acids res 2009; 1:443-447.

12. Centers for Disease Control and Preventionhttps://www.cdc.gov/drugresistance/about.html

13. World Health Organization. Antibiotic Resistance: Multi- country public awareness survey World Health Organization 2105. http://www.who.int/drugresistance/en/

14. Simpson SA, Wood F, Butler CC. General Practitioners' perceptions of antimicrobial resistance: a qualitative study. J AntimicrobChemother 2007; 59: 292-96.

15. Afzal Khan, A. K., et al. Antibiotic Resistance and Usage-A Survey on the Knowledge, Attitude, Perceptions and Practices among the Medical Students of a Southern Indian Teaching Hospital. J ClinDiag Res 2013; 16136.

16. Bing Lv, Zhongliang Zhou, GuipingXu, Dingkun Yang, Lina Wu, QianShen, et al. Knowledge, attitudes and practices concerning self-medication with antibiotics among university students in western China. TMIH 2014; 19 (769-779)

17. Austin DJ, Kristinsson KG \& Anderson RM. The relationship between the volume of antimicrobial consumption in human communities and the frequency of resistance. PNAS1999; 96, 1152-1156.

18. Martin J Llewelyn, Jennifer M Fitzpatrick, Elizabeth Darwin, SarahTonkinCrine, Cliff Gorton, John Paul, Tim E A Peto. The antibiotic course has had its day BMJ 2017; 358:3418.

19. Jamshed SQ, Elkalmi R, Rajiah K, Al-Shami AK, Shamsudin SH, Siddiqui MJ. Understanding of antibiotic use and resistance among final-year pharmacy and medical students: Apiolet study. J Infect DevCtries. 2014; 8:7805.

20. Huang, Ying. Knowledge, attitude and practice of antibiotics: a questionnaire study among 2500 Chinese students. BMC medical education 2013; 13.1: 163

21. Wessels, Michael R. Streptococcal pharyngitis. NEJM2011; 364.7: 648-655.

22. Paulo Martins da Costa, LuísLoureiro, and Augusto J. F. Matos. Transfer of Multidrug-Resistant Bacteria between Intermingled Ecological Niches: The Interface between Humans, Animals and the Environment. Int J Environ Res Public Health 2013; 10(1): 278-294.

23. Zhu, Yong-Guan. Diverse and abundant antibiotic resistance genes in Chinese swine farms. PNAS 2013; 110.9: 3435-3440.

24. Minen, Mia T. A survey of knowledge, attitudes, and beliefs of medical students concerning antimicrobial use and resistance. Microb Drug Resist.2010; 16.4: 285-289.

25. Compassion in World Farming .Antibiotics in Farm Animal Production. Public Health and Animal Welfare. Compassion in World Farming; 2011. [Accessed December 15, 2014].

26. Al-Tawfiq, Jaffar A., Gwen Stephens, and Ziad A. Memish. Inappropriate antimicrobial use and potential solutions: a Middle Eastern perspective. Expert review of anti-infective therapy 2010; 8.7: 765-774.

27. Al-Ghamdi MS, Al-Mustafa ZH, El-Morsy F, Al-Faky A, Haider I, Essa H. Residues of tetracycline compounds in poultry products in the eastern province of Saudi Arabia. Public Health 2000;114(4), 300-304. 